\title{
Efficiency and Profitability Analysis of Agricultural Cooperatives in Mpumalanga, South Africa
}

\author{
Thembi Xaba*, Nyankomo Marwa, Babita Mathur-Helm \\ University of Stellenbosch Business School, Bellville, South Africa \\ thembix@gmail.com,nyankomo@sun.ac.za,babita@sun.ac.za
}

\begin{abstract}
Agricultural cooperatives are expected to generate sustainable profit as they are established as a vehicle of economic development. Efficiency and profitability analysis measures the performance of a firm, and assists management in decision-making through benchmarking with other firms (Marwa \& Aziakpono, 2014). To understand the performance of agricultural cooperatives, our study analysed efficiency and profitability using an efficiency-profitability matrix to provide for multi-dimensional analysis. The study used secondary data from annual financial statements for the financial years 2015/16 collected from 19 agricultural cooperatives. Technical efficiency was estimated using Data Envelopment Analysis (DEA) and profitability was estimated using Returns on Assets (ROA). The median scores were $68 \%$ for technical efficiency and $10 \%$ for profitability. Using the $68 \%$ efficiency and $10 \%$ profitability benchmark, the matrix separated best performers from low performers. The matrix indicated that $26 \%$ of the cooperatives had highefficiency levels with high profitability (stars), however there was an even distribution between the stars and sleepers: 5 out of 19 cooperatives were sleepers and 5 out of 19 were stars. The majority of the decisionmaking units (DMUs) at $42 \%$ (8 out of 19) are in quadrant 3, categorised as 'question mark'. These DMUs had low-efficiency scores and low profitability ratios. Only 1 out of 19 cooperatives had high-efficiency levels and low profitability scores. The results demonstrate that technically efficient firms do not always translate to profitable firms: in this regard, management needs to investigate how best to allocate resources in order to remain relevant within the business context and competition. Policy makers need to investigate other drivers of efficiency and profitability when measuring the performance of a firm to influence future policy directives.
\end{abstract}

\section{Keywords: Agricultural cooperatives, profitability, efficiency, Mpumalanga, South Africa}

\section{Introduction}

Cooperatives are formed as a vehicle of economic development, as members or small producers combine to capture economies of size, and therefore have bargaining power (Lerman \& Parliament, 1991). In South Africa agricultural cooperatives are regulated under the Cooperative Act of 2005, and the cooperatives are regarded as a vehicle to economic inclusion (Ortmann \& King, 2007a). The Act defines an agricultural cooperative as 'a co-operative that produces processes or markets agricultural products and supplies agricultural inputs and services to its members. The major role of the Cooperative Act has been to coordinate functions such that cooperatives promote economic and social development through employment creation and generating income (Ortmann \& King, 2007a). Since the enactment of the Cooperative Act, there have been concerns over whether the cooperatives are achieving economic and social development goals (Ortmann \& King, 2007b; Chibanda, Ortmann \& Lyne, 2009).

Performance evaluation is important, as it enables the firm to identify underlying problems, and to benchmark with other firms in the industry (Charnes and Cooper, 1984). Performance analysis is also important as it is considered a significant factor in driving the survival of a firm (Keramidou, Mimis, Fotinopoulou, \& Tassis, 2013). This study employs performance measurement through efficiency and profitability analysis. The objective of the study is to establish if the cooperatives as organisations are efficient and profitable, can withstand economic shocks, and are able to achieve economic gains for its members or patrons. The study also tests the correlation between efficiency and profitability, that is, whether efficient cooperatives are also profitable. Data Envelopment Analysis (DEA) was employed to measure efficiency and Return on Assets (ROA) was used to measure profitability. The study further employed the profitability-efficiency matrix to determine the correlation between profitability and efficiency, separating the best performers from low performers. 


\section{Theoretical Literature Review}

Cooperative as a Firm (Theory of a Firm): Studies of cooperative behaviour linked to firms have always advanced that agricultural cooperatives seek to minimise costs or inputs with the objective of maximising profits (Helmberger \& Hoos, 1962; Aoki, 1984). Helmberger and Hoos used the neo-classical theory of the firm to develop short-run and long-run models of a cooperative, where each firm maximises its profits subject to its cost structure and product demand constraints (Helmbeger \& Hoos, 1962). However, Emelianoff argued that cooperatives should be viewed as aggregate economic units, with a vertical integration model, where each independent enterprise seeks to maximise profits (Emelianoff, 1995). The extension of this argument is augmented by Phillips, who holds that cooperatives are vertically integrated firms, as the associated firms must each allocate resources to a common plant (Phillips, 1953). This theory underpins that a single integrated firm maximises profits through inputs from different firms, performing different functions, and yet are brought under single managerial control (Emelianoff, 1995; Helmberger \& Hoos, 1962).

However fundamental problems have been pointed out from the vertical firm theory and profit maximisation objective, citing the agency problem where the objectives of the agent are not the same as that of the principal (Sykuta \& Chaddad, 1999). The challenges are horizon problems, as cooperatives are seen to be focusing on short-term earnings rather than long-term earnings and sustainability (Porter \& Scully, 1987; Ortmann \& King, 2007b). It is also noted that cooperatives not only address the profit maximisation role, but they also need to balance social needs through economic fairness by equal access to markets, which means that over and above profitability the interests of the community become paramount (Schwettmann, 1997). Another argument advanced by Sexton and Iskow (1988) is that performance of a joint entity might be distorted, as different entities each have their own assets and can shift income from one entity to another. Having noted the conflicting measurement gaps, the fundamental objection remains that cooperative members are more concerned about the financial performance of their entity (Hardesty \& Salgia, 2003).

Suffice it to say, as much as members are entitled to the net income generated by the cooperative, they are equally residual risk bearers of the firm's net cash flow (Soboh, Lansink, Giesen \& Van Dijk, 2009). Notwithstanding the above, this study acknowledges the opposing views, however it has adopted the classical theory of a firm, that of cost minimisation and maximising output for profit maximisation, as across various theories, the common goal of profit maximisation is evident, with economic gains for economic advancement in developing economies. The adoption is also consistent with the theory adopted in the preceding paper on efficiency measurement, where the classical theory of a firm was adopted, with the objective of cost minimisation and profit maximisation (Helmberger \& Hoos, 1962). This literature review section follows with a look at agricultural cooperatives and efficiency evaluation, and agricultural cooperatives and profitability evaluation.

Agricultural Cooperatives and Efficiency Evaluation: Performance evaluation through efficiency measurement analyses the ability of a firm to produce the maximum output possible given input constraints (Coelli, Rao, O'Donnell \& Battese, 2005). According to Koopmans (1951), an input-output vector is technically efficient only if increasing any output or decreasing any input is possible by decreasing some other output or increasing some other input (Koopmans, 1951). This study employs technical efficiency (TE) which measures the performance of a firm using the extent to which it deviates from the best practice frontier given a specific dimension: cost, inputs, output or profit (Marwa \& Aziakpono, 2016). A firm is only technically efficient if it operates on the frontier and all associated slacks are zero (Debreu, 1951). Efficiency can be measured with either accounting or economic methods. The accounting principle applies ratios as a measure of efficiency (Charnes \& Cooper, 1984; Halkos \& Salamouris, 2004). Economic methods present various techniques of measuring efficiency and TE: however, frontier estimation models such as Stochastic Frontier Analysis (SFA) and Data Envelopment Analysis (DEA) generally dominate (Marwa \& Aziakpono, 2016).

Stochastic Frontier Analysis: SFA is a parametric approach which can estimate the productivity and efficiency of a decision-making unit (DMU). SFA was developed on theoretical literature of productive efficiency (Meeusen \& Van Den Broeck, 1977; Aigner, Lovell \& Schmidt, 1977), and resulted in developing the production frontier context (Kumbhakar \& Lovell, 2000). SFA creates a framework that can analyse firms that do not succeed in optimisation, or are not fully efficient, by comparing firms to 'best practice' (Cummins, Feng 
\& Weiss, 2012). According to Andor \& Hesse (2011), the limitation of SFA is that the best it can do is to obtain a 'mean' efficiency over a sample.

Data Envelopment Analysis: DEA, as developed by Charnes, Cooper and Rhodes in 1978, known as the CCR model, introduced the efficiency measurement which generalised the single output and single input ratio to multiple inputs and outputs without requiring pre-assigned weights (Charnes \& Cooper, 1984). The methodology emerged as an alternative to the traditional regression method analysis. The units that lie in the 'surface' are defined as 'efficient' DMUs (Murillo-Zamorano, 2004). The limitation of DEA is its 'nonstochastic' nature: it does not account for statistical noise (Lovell, 1994). However, this limitation is addressed by employing a bootstrapping method (Efron \& Tibshirani, 1998; Simar \& Wilson, 2000). For efficiency measurement, this study adopted the DEA: Liu, Lu, Lu and Lin (2013), having surveyed DEA applications, found that DEA was more robust in measuring efficiency than parametric approaches from 1978 to 2000, in which agriculture efficiency analysis was listed within the top five applications in which DEA had been applied. DEA deals with individual DMUs as opposed to the population average, it utilises $n$ optimisation for each DMU, which makes DEA results more reliable (Moffat, 2008).

Agricultural Cooperatives and Profitability Evaluation: Profitability is the primary goal of any business venture (Hofstrand, 2009). It can be measured as the net income over total expenses or the excess revenue over total expenses, or by return on assets (ROA) which is income before interest and taxes divided by total assets (Moller, Featherstone \& Barton, 1996; Marwa \& Aziakpono, 2014). Within the theory of the firm, optimal prices and quantities are determined by setting the cooperative's marginal cost equal to the marginal revenue and therefore the profit becomes the cooperative performance indicator (Soboh et al., 2009). It is noted that cooperatives behave differently in establishing profitability as they are user-owned, user-benefit, and user-controlled and they serve the interest of the members (Hardesty \& Salgia, 2003, Ortmann \& King, 2007b). The economic benefit of members remains the core foundation for income generation and sustainability, and as owners (residual claimants) members are entitled to the net income generated by the firm (Ortmann \& King, 2007b; Soboh et al., 2009). Theory indicates that profitability can be measured through economic perspective or accounting perspective (Sexton \& Iskow, 1988). The accounting model applying financial ratios to determine the performance of a firm can employ liquidity ratios, asset efficiency, profitability and leveraging for performance measurement. Empirical studies have always employed the traditional financial ratio method to measure the performance and profitability of a cooperative (Marwa \& Aziakpono, 2014).

\section{Empirical Literature Review}

Agricultural Cooperatives and Efficiency: Studies on whether agricultural cooperatives are efficient have not yielded similar results. Tipi, Yildiz, Nargelecekenler and Cetin (2009) investigated the performance and TE and the determinants of rice farms in Turkey using an input-oriented DEA model to measure TE scores, and Tobit regression. The regression estimates showed TE was negatively influenced by a number of farmers, age, plot size and off-farm income (Tipi et al., 2009). Soboh et al. (2012) compared dairy cooperatives and investor-owned firms in Europe to measure performance, applying DEA to measure efficiency. They argued that economic literature had limitations in terms of measuring the performance of cooperatives and found that cooperatives' performance was influenced by members' objectives (Soboh et al., 2012). In South Africa, Piesse, Doyer, Thirtle and Vink (2005) investigated the efficiency levels of grain cooperatives in competitive markets using DEA and financial ratios, and found that increased competition led to increased efficiency of cooperatives (Piesse et al., 2005)

Agricultural Cooperatives and Profitability: The accounting method profitability analysis using ROA has been adopted by various studies. Many studies have compared the performance of cooperatives with investor-owned firms, with results signifying that cooperatives were less efficient and profitable than investor-owned firms (Lermann \& Parliament, 1991; Hardesty \& Salgia, 2003). Hardesty and Salgia used traditional financial ratios to measure performance through testing profitability, liquidity, and leverage and asset efficiency of investor-owned firms against those of cooperatives. They found that, overall, cooperatives demonstrated low rates of asset efficiency, and yet the relative profitability and liquidity was not conclusive (Hardesty \& Salgia, 2003). These mixed results are also found in a study by Schrader, where Midwestern 
cooperatives results between 1979-1983 found cooperatives had various functions and similar rates of return, whilst large diversified investor-owned businesses had high ROA compared to cooperatives (Schrader, 1989). The above studies demonstrate that measuring financial performance employing traditional ratios such as return on assets (ROA) and return on equity (ROE) has been tested on cooperatives. This study focuses on ROA as a measurement for profitability, as opposed to ROE. The argument is that with ROE, cooperatives have limited return on equity capital as the business pays strictly limited dividends on equity capital invested in the organisation (Staatz, 1987). Another limitation is that the value of an enterprise may exceed the value of members' patronage (Schrader, 1989). In the South African context, since agricultural cooperatives are funded by the government, employing ROE will distort the performance results.

Agricultural Cooperatives' Efficiency and Profitability: The debate on whether firm efficiency is directly related to profitability has received varying results. Camanho and Dyson (1999) measured branches of a Portuguese bank and found that branches' efficiency has a positive effect on profits, although high profitability is not necessarily directly related to high efficiency. However, in a study of Tanzanian financial cooperatives, the results demonstrated that the majority had low profitability and low-efficiency levels (Marwa \& Azikapono, 2014). A study by Keramidou et al. of meat processing companies in Greece interrogated the relationship between efficiency and profitability by applying a decomposition model. The results indicate that there was no strong positive correlation between profitability and efficiency (Keramidou et al., 2013). Hence, there is a need to explore both explore both dimensions in empirical studies. With this study ROA becomes a realistic measure, noting that all the financial statements provided by the agricultural cooperatives have total assets as a variable.

\section{Methodology}

This study used data from the DAFF's 2015/16 Annual Report on cooperatives. South Africa had a total of 2,682 agricultural cooperatives, of which 571 were in Mpumalanga: however, the number of operational cooperatives was not ratified. The inclusion criteria in the study were the cooperatives that complied with reporting on audited annual financial statements. The study selected the 19 agricultural cooperatives that had complied with Annual Financial Statement (AFS) reporting. The data was available from the Mpumalanga Department of Agriculture, and permission was sought to use the data for the preliminary study. To recap on the study on technical efficiency on the preceding paper (awaiting publication) on efficiency evaluation of agricultural cooperatives, the efficiency scores were measured where technical efficiency was decomposed into pure technical efficiency and scale efficiency using DEA. In this study, a frontier function approach was employed. The frontier methodology technique presents the benchmarking model between DMUs: it measures how a DMU is performing relative to its peers. Frontiers are important for the prediction of technical inefficiencies in the industry (Batesse \& Coelli, 1991). It is widely used in agriculture due to its consistency in production, profit and cost functions, with the notion of minimising input or output orientation, or maximising profit (Bravo-Ureta \& Pinheiro, 1993).

Measuring Technical Efficiency: Input variables were total assets and total expenses, and output variables were revenue and profit. From the mathematical computation, the formulation of the problem was that cooperatives are treated as firms. In this regard firms seek to minimise inputs and maximise outputs, therefore the function was on cost minimisation and adopted a mathematical model by Coelli et al. (2005).

$\operatorname{Min} \theta$, subject to $-q_{i}+Q \lambda \geq 0, \theta x_{i}-X \lambda \geq 0$, $\lambda \geq 0$

Where $\theta$ is a scalar and $\lambda$ is a $I \times 1$ vector of constants. The value $\theta$ obtained is the efficiency score for the $i$ th firm and satisfies $0 \leq \theta \leq 1$. In this regard, the value 1 indicates a firm lying on the frontier and therefore the firm is known to be technically efficient, according to the definition of Farrell (1957). Technical efficiency (TE) can be decomposed into Pure Technical Efficiency (PTE) and Scale Efficiency (SE). DEA was applied to decompose the results. In other words, TE $=\mathrm{PTE} * \mathrm{SE}$, and in most instances DEAP 2.1 software is able to give only TE and SE, but PTE $=$ TE/SE.

Profitability: For profitability analysis the data from 19 agricultural cooperatives were used, with their financial statements for the financial year 2015/16. The data were sourced from the Mpumalanga 
Department of Agriculture as secondary data. The methodology employed the traditional ratio analysis of ROA. As indicated in the literature review, ROE tends to overcompensate on equity against member patronage. ROA is arguably the most popular and user-friendly to managers for profitability analysis across firms (Joo, Nixon \& Stoeberl, 2011). In essence, ROA gives a measurement on return: how much the return is for every rand invested. This approach is further entrenched by the observation that all the agricultural cooperatives selected had reported on their total assets rather than on equity.

ROA was measured using the following formula:

$$
\mathrm{ROA}=\frac{\text { net income }}{\text { Total assets }}
$$

Efficiency/Profitability Matrix: This study also created an efficiency and profitability matrix, which provides management with an opportunity to review which areas they can improve to achieve higher profitability (Camanho \& Dyson, 1999). The efficiency profitability matrix adopted has been employed as a comprehensive measure of performance through various dimensions (Camanho \& Dyson, 1999; Keramidou et al., 2013; Marwa \& Azikapono, 2014). This model separates the firms' performance levels in four quadrants, where quadrant I represents the sleepers, II represents the stars, III represents the question marks, and IV represents the dogs. Best performers are firms with high-efficiency levels and high profitability ratios. The stars are those DMUs that have high-efficiency levels and high profitability, which means these firms convert their inputs into outputs efficiently while at the same time recording high profits (Camanho \& Dyson, 1999). The sleepers are DMUs with high profitability but low-efficiency levels. The dogs are DMUs with high-efficiency levels with low profitability, and the question marks are DMUs with low-efficiency levels and low profitability ratios (Kumar, 2008). This matrix followed work done by Boussofiane, Dyson and Thanassoulis (1991). The matrix deals with the limitation pointed out in using traditional financial ratios as a measurement, the argument is that it provides a 'snapshot' of the organisation's performance (Altman, 1968; Yeh, 1996). Stata was used to compute the results of the various quadrants, with efficiency plotted against the $x$-axis and profitability against the $y$-axis.

\section{Results}

Descriptive Results: Table 1 below gives a summary of our results from the 19 agriculture cooperatives using Data Envelopment Analysis Program (DEAP) version 2.1 developed by Coelli (1996).

Table 1: Efficiency Results

\begin{tabular}{ccccl}
\hline DMU \# & Technical Efficiency & Pure Technical Efficiency & Scale Efficiency & Returns to Scale \\
\hline 1 & 0.501 & 0.502 & 0.999 & - \\
2 & 0.516 & 0.519 & 0.994 & Irs \\
3 & 0.670 & 1.000 & 0.670 & Drs \\
4 & 0.598 & 0.697 & 0.858 & Drs \\
5 & 0.691 & 1.000 & 0.691 & Drs \\
6 & 0.687 & 1.000 & 0.687 & Irs \\
7 & 0.694 & 0.835 & 0.831 & Drs \\
8 & 1.000 & 1.000 & 1.000 & - \\
9 & 0.675 & 1.000 & 0.675 & Drs \\
10 & 1.000 & 1.000 & 1.000 & - \\
11 & 0.945 & 0.969 & 0.975 & Drs \\
12 & 0.192 & 0.322 & 0.597 & Drs \\
13 & 1.000 & 1.000 & 1.000 & - \\
14 & 0.574 & 0.575 & 0.999 & Irs \\
15 & 0.667 & 0.696 & 0.959 & Drs \\
\hline
\end{tabular}




\begin{tabular}{cllll}
\hline 16 & 0.746 & 0.750 & 0.995 & Irs \\
17 & 1.000 & 1.000 & 1.000 & - \\
18 & 0.769 & 0.952 & 0.808 & Drs \\
19 & 0.671 & 0.865 & 0.776 & Drs \\
Median & $\mathbf{0 . 6 8}$ & $\mathbf{0 . 9 5}$ & $\mathbf{0 . 9 5}$ & \\
\hline
\end{tabular}

Source: Authors' computation

From the results, the median score for efficiency is $68 \%$, which means that the DMU's combined efficiency rate was at $68 \%$, and there is a resource wastage of $32 \%$. What is interesting to note is that when the observation is done on individual DMUs, only $21 \%$ of the DMUs are $100 \%$ technically efficient, operating at constant returns to scale (CRS). From the efficiency analysis, profitability was decomposed using the ROA methodology. Each DMU efficiency was then measured against profitability. Table 2 below shows the performance comparison for each DMU on efficiency and profitability. This firm has to look at how best to position itself in the market to increase its profitability levels. The results are consistent with the previous studies, which demonstrated there was no positive correlation between efficiency levels and profitability (Camhano \& Dyson, 1999: Kumar, 2008; Marwa \& Aziakpono, 2014).

Table 2: Technical Efficiency and Profitability Measure Comparison

\begin{tabular}{|c|c|c|c|}
\hline DMU \# & DMU & EFFICIENCY & PROFIT (\%) \\
\hline 1 & $\mathrm{~A}$ & 0.501 & -336 \\
\hline 2 & B & 0.516 & 0.03 \\
\hline 3 & $\mathrm{C}$ & 0.67 & 8.91 \\
\hline 4 & $\mathrm{D}$ & 0.598 & -61.15 \\
\hline 5 & E & 0.691 & 25.5 \\
\hline 6 & $\mathrm{~F}$ & 0.687 & 25.00 \\
\hline 7 & G & 0.694 & 9.71 \\
\hline 8 & $\mathrm{H}$ & 1 & 100 \\
\hline 9 & I & 0.675 & 10.25 \\
\hline 10 & $\mathrm{~J}$ & 1 & 100 \\
\hline 11 & K & 0.945 & 77.73 \\
\hline 12 & $\mathrm{~L}$ & 0.192 & -44.69 \\
\hline 13 & M & 1 & -46.68 \\
\hline 14 & $\mathrm{~N}$ & 0.574 & 3.47 \\
\hline 15 & 0 & 0.667 & 1.38 \\
\hline 16 & $\mathrm{P}$ & 0.746 & 7.59 \\
\hline 17 & $Q$ & 1 & 76.36 \\
\hline 18 & $\mathrm{R}$ & 0.769 & 29.30 \\
\hline \multirow[t]{2}{*}{19} & S & 0.671 & 20.91 \\
\hline & Median & $68 \%$ & $10 \%$ \\
\hline
\end{tabular}

Source: Authors' computation

When we compare employ profitability scores, the median for profitability is $10 \%$ as seen in Table 2 and $37 \%$ of DMUs are above the 10\% average. Having decomposed technical efficiency and profitability as shown in Tables 1 and 2, the technical efficiency and profitability dimension was employed to test if there is a positive correlation between efficiency levels and profitability. Figure 1 below provides a descriptive view of the performance, with some DMUs operating at above efficiency levels, and some operating at a loss (less than $0 \%$ return rate). 
Figure 1: Technical Efficiency and Profitability Scores

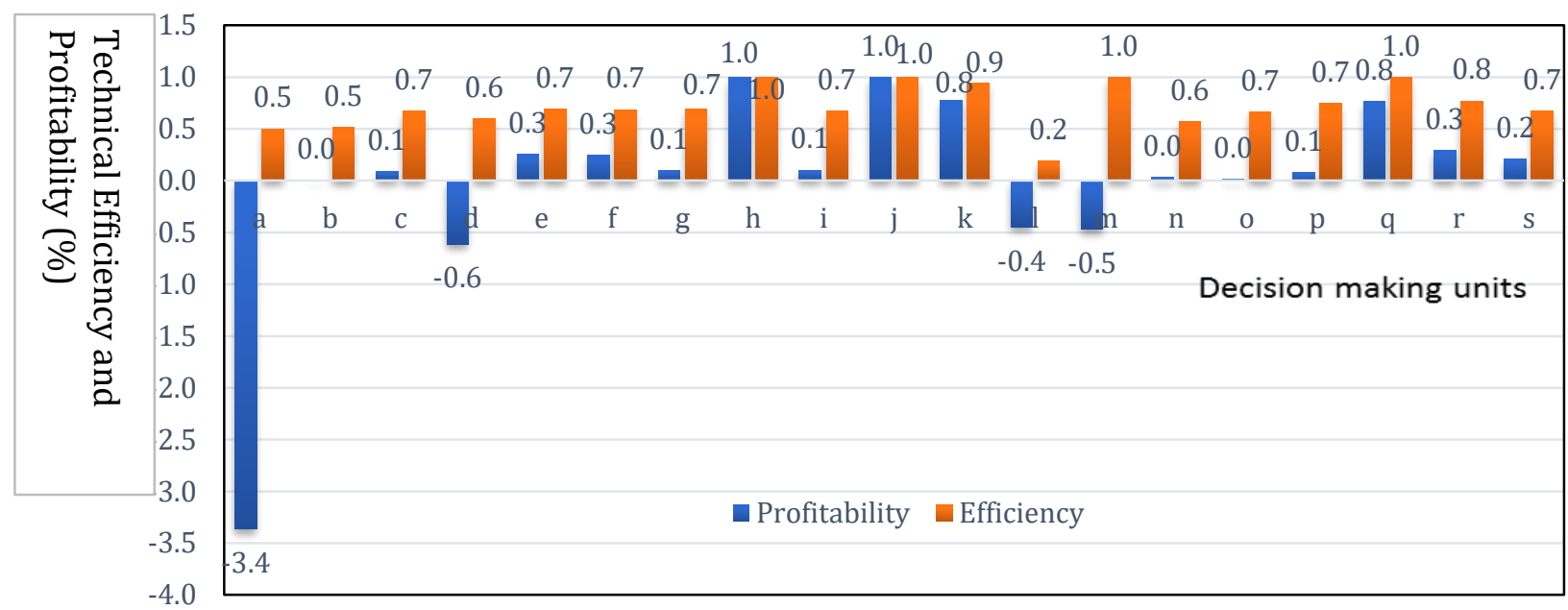

Source: Authors' computation

Profitability and Efficiency Matrix: This study also created an efficiency and profitability matrix, which provides management with an opportunity to review as to which areas they can improve to achieve higher profitability (Camanho \& Dyson, 1999). This matrix follows work done by Boussofiane et al. (1991), and has been further adopted by various studies measuring the relationship between efficiency and profitability for determining best performers (Camanho \& Dyson, 1999; Kumar, 2008; Marwa \& Aziakpono, 2014). Table 3 shows the profitability/ efficiency matrix results, and the quadrants expanding their performance measure, using STATA 14. Quadrant I shows sleepers, quadrant II stars, quadrant III question marks and quadrant IV dogs.

Figure 2: Descriptive Quadrants for Performance of DMUs

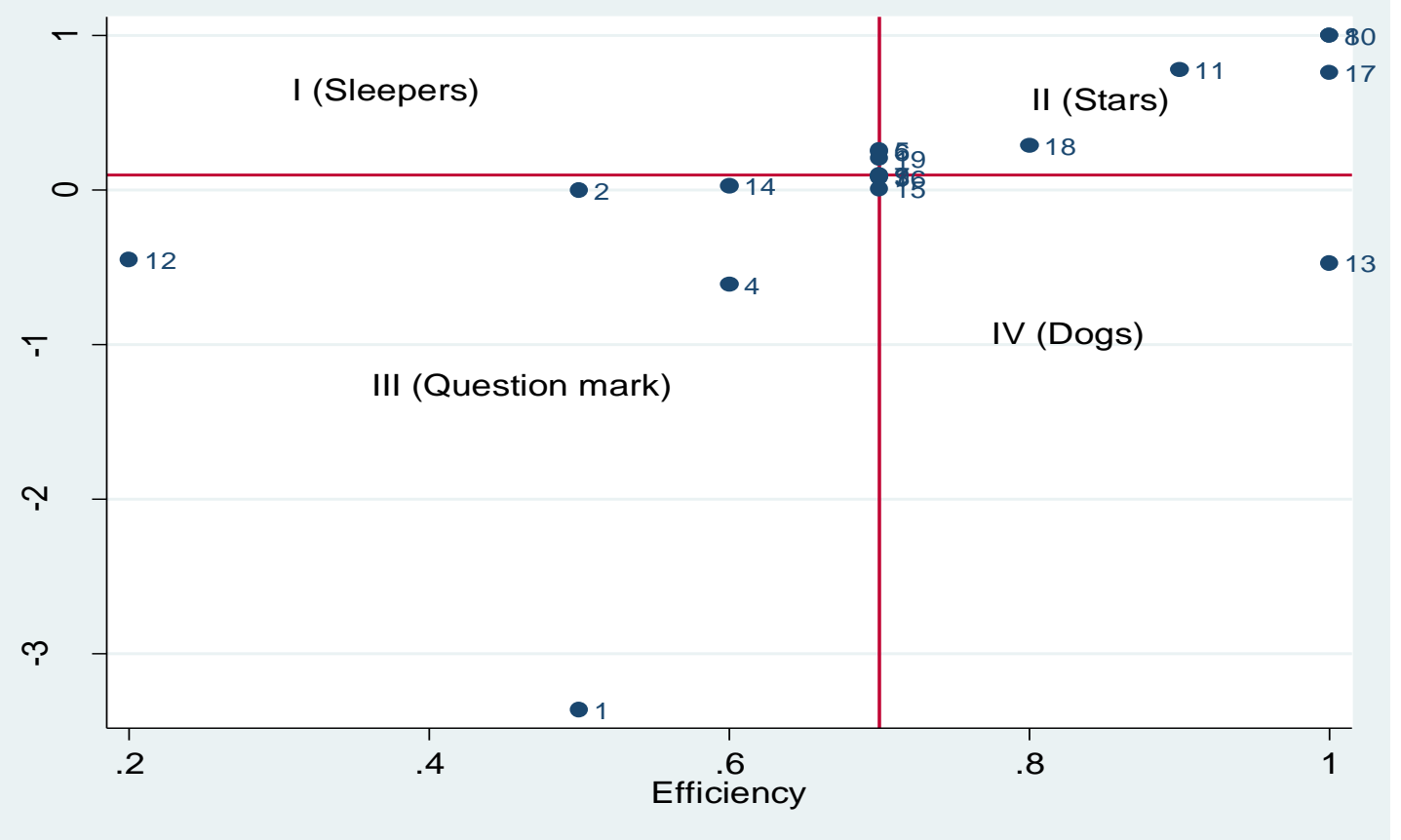

Source: Authors' computation 
The number of DMUs per quadrant is reflected in Table 3 below, with the frequency of DMUs in each quadrant.

Table 3: Frequency of DMUs in Quadrants

\begin{tabular}{lcc}
\hline Matrix & Frequency & Percent \\
\hline I (Stars) & 5 & 26.32 \\
II (Sleepers) & 5 & 26.32 \\
III (?) & 8 & 42.11 \\
IV (Dogs) & 1 & 5.26 \\
Total DMU & 19 & 100 \\
\hline
\end{tabular}

Source: Authors' computation

Discussion: From the above, it can be seen that there is an even distribution between the stars and sleepers in the quadrants, $26 \%$ of the firms have high efficiency and high profitability, these firms are best performers and considered as stars. What this means is that 5 out of 19 cooperatives have high-efficiency levels with high profitability ratios (stars), and also 5 out of 19 have high profitability and low-efficiency levels (sleepers), these DMUs (sleepers) are found in the borders of the quadrants (DMUs 5, 6, 7, 9 and 19). The sleepers will have to improve their resource allocation, which may result in them moving to the stars quadrant. The majority of the DMUs (8 out of 19) are in quadrant 3 (question marks), meaning they have low-efficiency levels and low profitability. These firms need to reconsider their operations as there are resource wastages, and the firms should also look at whether their businesses are facing challenging economic conditions such as competition, economic downturn, or if their service is still relevant in the market. Only one DMU was in quadrant 4 (dogs), this firm has a high-efficiency level and low profitability level. This firm is utilising resources efficiently and yet operating at a loss.

\section{Conclusion and Recommendations}

The study tested efficiency levels and profitability ratios of agricultural cooperatives, linking efficiency levels with profitability to see if efficient firms are equally profitable. The technical efficiency median was $68 \%$, and the profitability median was $10 \%$. The study further employed the efficiency/profitability matrix, and the results separate the best performers from those firms who are not performing on both efficiency and profitability. There was an even distribution between sleepers and stars, but it concerns that the majority of the firms were in the question mark quadrant. Only five DMUs (26\%) were found to be efficient and profitable, meaning the firms met the means of $68 \%$ and $10 \%$ profitability respectively. Efficiency does not always translate to profitability, there is a need for managers to continuously measure performance and investigate areas of improvement. Management has a role to play in efficient resource allocation to ensure there are no wastages. The existence of a firm does not mean that it is performing well financially: the weaknesses and characteristics of an organisation can only be established if there is continuous monitoring, focusing not only on one variable of performance, but employing a multi-dimensional approach to investigate areas of improvement.

Noting that efficiency and profitability are not always positively correlated, managers should understand a cooperative as a business as well as its social role towards economic development. Firms need to continuously follow the market and be in a position to respond to business competition. It concerns to see that the profitability of agricultural cooperatives is not witnessed across all firms. In this regard, policymakers should appreciate that agricultural cooperatives as firms also have a socio-economic role and members' patronage is inherent as they are user-owned and user-controlled. Future policy decisions should factor in empowering the agricultural cooperatives as firms, for them to be able to manage resources efficiently while at the same time being profitable, resulting in sustainable organisations. It is also important that agricultural cooperatives find the balance between their social role and economic development, such as that of member patronage benefit linked to positive financial benefit. Members of cooperatives also need to review their stance on taking the cooperative as a business, rather than an entity that services users' needs. 
There is a need for a turnaround strategy to ensure that there is focus on efficient resource allocation and there are measures and systems to stay abreast with the market and competition for their survival.

\section{References}

Aigner, D., Lovell, C. K. \& Schmidt, P. (1977). Formulation and estimation of stochastic frontier production function models. Journal of Econometrics, 6(1), 21-37.

Altman, E. I. (1968). Financial ratios, discriminant analysis and the prediction of corporate bankruptcy. The Journal of Finance, 23(4), 589-609.

Andor, M. \& Hesse, F. (2011). A Monte Carlo simulation comparing DEA, SFA and two simple approaches to combine efficiency estimates. CAWM Discussion paper no. 51. Centre of Applied Economic Research, University of Münster.

Aoki, M. (1984). The co-operative game theory of the firm. Oxford University Press.

Batesse, G. E. \& Coelli, T. J. (1991). Frontier production functions, technical efficiency and panel data: with applications to paddy farmers in India. In Gulledge, T. R. \& Knox Lovell, C. A. (eds.), International Applications of Productivity and Efficiency Analysis (149-165). Netherlands: Springer.

Boussofiane, A., Dyson, R. G. \& Thanassoulis, E. (1991). Applied data envelopment analysis. European Journal of Operational Research, 52(1), 1-15.

Bravo-Ureta, B. E. \& Pinheiro, A. E. (1993). Efficiency analysis of developing country agriculture: a review of the frontier function literature. Agricultural and Resource Economics Review, 22(1), 88-101.

Camanho, A. S. \& Dyson, R. G. (1999). Efficiency, size, benchmarks and targets for bank branches: an application of data envelopment analysis. Journal of the Operational Research Society, 50(9), 903-915.

Charnes, A. \& Cooper, W. W. (1984). Preface to topics in data envelopment analysis. Annals of Operations Research, 2(1), 59-94.

Charnes, A., Cooper, W. W. \& Rhodes, E. (1978). Measuring the efficiency of decision-making units. European Journal of Operational Research, 2(6), 429-444.

Chibanda, M., Ortmann, G. F. \& Lyne, M. C. (2009). Institutional and governance factors are influencing the performance of selected smallholder agricultural cooperatives in KwaZulu-Natal. Agrekon, 48(3), 293-315.

Coelli, T. (1996). A guide to DEAP version 2.1: a data envelopment analysis (computer) program. Australia: Centre for Efficiency and Productivity Analysis, University of New England.

Coelli, T. J., Rao, D. S. P., O’Donnell, C. J. \& Battese, G. E. (2005). An introduction to efficiency and productivity analysis. Springer Science \& Business Media.

Cummins, J. D., Feng, Z. \& Weiss, M. A. (2012). Reinsurance counterparty relationships and firm performance in the US property-liability insurance industry. Draft paper submitted to Temple University.

Debreu, G. (1951). The coefficient of resource utilization. Econometrica, 19(3), 273-292.

Department of Agriculture, Forestry and Fisheries (DAFF). (2015). The 5th annual report of the status of cooperatives in the sector 2015/16. Pretoria: Government Printer.

Efron, B. \& Tibshirani, R. J. (1998). An introduction to the bootstrap. Monograph on statistics and applied probability. Washington DC: Chapman \& Hall/CRC.

Emelianoff, I. (1995). Economic theory of cooperation: Economic structure of cooperative organizations, 1948, reprinted by the Center for Cooperatives. University of California.

Farrell, M. J. (1957). The measurement of productive efficiency. Journal of the Royal Statistical Society. Series A (General), 120(3), 253-29.

Halkos, G. E. \& Salamouris, D. S. (2004). Efficiency measurement of the Greek commercial banks with the use of financial ratios: a data envelopment analysis approach. Management Accounting Research, 15(2), 201-224.

Hardesty, S. D. \& Salgia, V. D. (2003). Comparative financial performance of agricultural cooperatives and investor-owned firms. NCERA-194 Research on Cooperatives, 2004 Annual Meeting, November 2-3.

Helmberger, P. G. \& Hoos, S. (1962). Cooperative enterprise and organization theory. Journal of Farm Economics, 44(2), 275-90.

Hofstrand, D. (2009). Understanding profitability. Ag Decisions Makers, 2, C3-24.

Joo, S. J., Nixon, D. \& Stoeberl, P. A. (2011). Benchmarking with data envelopment analysis: a return on asset perspective. Benchmarking: An International Journal, 18(4), 529-542. 
Keramidou, I., Mimis, A., Fotinopoulou, A. \& Tassis, C. D. (2013). Exploring the relationship between efficiency and profitability. Benchmarking: An International Journal, 20(5), 647-660.

Koopmans, T. C. (1951). Efficient allocation of resources. Econometrica, 19(4), 455-465.

Kumar, S. (2008). An analysis of efficiency-profitability relationship in Indian public sector banks. Global Business Review, 9(1), 115-129.

Kumbhakar, S. C. \& Lovell, C. A. K. (2000). Stochastic frontier analysis. United States of America: Cambridge University Press.

Lerman, Z. \& Parliament, C. (1991). Size and industry effects in the performance of agricultural cooperatives. Agricultural Economics, 6(1), 15-29.

Liu, J. S., Lu, L. L. Y., Lu, W. M. \& Lin, B. J. Y. (2013). A survey of DEA applications. International Journal of Management Sciences, 41(5), 893-902.

Lovell, C. A. K. (1994). Linear programming approaches to the measurement and analysis of productive efficiency. Top, 2(2), 175-248.

Marwa, N. \& Aziakpono, M. (2014). Efficiency and profitability of Tanzanian saving and credit cooperatives: who is a star? Journal of Economics and Behavioral Studies, 6(8), 658-669.

Marwa, N. \& Aziakpono, M. (2016). Technical and scale efficiency of Tanzanian saving and credit cooperatives. Journal of Developing Areas, 50(1), 29-46.

Meeusen, W. \& van Den Broeck, J. (1977). Efficiency estimation from Cobb-Douglas production functions with composed error. International Economic Review, 18(2), 435-444.

Moffat, B. D. (2008). Efficiency and productivity in Botswana's financial institutions. PhD thesis submitted to the University of Wollongong.

Moller, L. G., Featherstone, A. M. \& Barton, D. G. (1996). Sources of financial stress in agricultural cooperatives. Journal of Cooperatives, 11, 38-50.

Murillo-Zamorano, L. R. (2004). Economic efficiency and frontier techniques. Journal of Economic Surveys, 18(1), 33-77.

Ortmann, G. F. \& King, R. P. (2007a). Agricultural cooperatives I: History, theory and problems. Agrekon, 46(1), 18-46.

Ortmann, G. F. \& King, R. P. (2007b). Agricultural cooperatives II: can they facilitate access of small-scale farmers in South Africa to input and product markets? Agrekon, 46(2), 219-244.

Phillips, R. (1953). Economic nature of the cooperative association. Journal of Farm Economics, 35(1), 74-87.

Piesse, J., Doyer, T., Thirtle, C. \& Vink, N. (2005). The changing role of grain cooperatives in the transition to competitive markets in South Africa. Journal of Comparative Economics, 33(1), 197-218.

Porter, P. K. \& Scully, G. W. (1987). Economic efficiency in cooperatives. The Journal of Law and Economics, 30(2), 489-512.

Republic of South Africa. (2005). Cooperative Act 14 of 2005. Pretoria: Department of Trade and Industry.

Schrader, L. F. (1989). Equity capital and restructuring of cooperatives as investor-oriented firms. Journal of Agricultural Cooperation, 4, 41-53.

Schwettmann, J. (1997). Cooperatives and employment in Africa. Geneva: ILO.

Sexton, R. J. \& Iskow, J. (1988). Factors critical to the success or failure of emerging agricultural cooperatives. Giannini Foundation Information Series No. 88-3. Davis: Division of Agriculture and Natural Resources, University of California.

Simar, L. \& Wilson, P. W. (2000). Statistical inference in nonparametric frontier models: The state of the art. Journal of Productivity Analysis, 13(1), 49-78.

Soboh, R. A., Lansink, A. O., Giesen, G. \& Van Dijk, G. (2009). Performance measurement of the agricultural marketing cooperatives: the gap between theory and practice. Review of Agricultural Economics, 31(3), 446-469.

Staatz, J. M. (1987). The structural characteristics of farmer cooperatives and their behavioral consequences. Cooperative Theory: New Approaches, 18, 33-60.

Sykuta, M. E. \& Chaddad, F. R. (1999). Putting theories of the firm in their place: A supplemental digest of the new institutional economics. Journal of Cooperatives, 14(1), 68-76.

Tipi, T., Yildiz, N., Nargelecekenler, M. \& Cetin, B. (2009). Measuring the technical efficiency and determinants of technical efficiency of rice farms in Marmara region, Turkey. New Zealand Journal of Crop and Horticultural Science, 37(2), 121-129.

Yeh, Q. J. (1996). The application of data envelopment analysis in conjunction with financial ratios for bank performance evaluation. Journal of the Operational Research Society, 47(8), 980-988. 